\title{
TOURISM, FARM DIVERSIFICATION AND PLURALITY OF RURALITY: CASE STUDY OF CROATIA
}

\author{
Aleksandar Lukić ${ }^{1}$
}

Received 20 November 2012; Accepted 12 April 2013

\begin{abstract}
Plurality is considered to be one of the most important indicators of rurality in the contemporary society. But in what sense can plurality and diversified geographic context of countryside make a difference for development of farm tourism, if any? This paper aims to explore the significance of rural diversity of Croatia for farm diversification into leisure-orientated activities. The main method is comparison of spatial distribution of those farms, on the one hand, and seven different types of rural areas, on the other. Among others, the results indicate the significance of overall (mass) tourism development along the coast for development of tourism on agricultural households. Furthermore, age and education are confirmed as important factor in the process.
\end{abstract}

Key words: farm tourism, farm diversification, rural typology, rural tourism, factor analysis, cluster analysis, Croatia

Sažetak: Pluralnost je jedan od najznačajnjih suvremenih obilježja ruralnosti. No imaju li pluralnost i diverzificiranost geografskih obilježja ruralnih područja utjecaja na razvoj turizma na seljačkim domaćinstvima? Cilj ovog istraživanja jest istraživanje važnosti različitih tipova ruralnih područja za diverzifikaciju seljačkih domaćinstava i pružanje turističkih sličnih usluga. Osnovna istraživačka metoda jest usporedba prostornog razmještaja takvih domaćinstava s sedam različitih tipova ruralnih područja koji su određeni tehnikama multivarijatne (faktorske i klaster) analize. Rezultati, među ostalim, upućuju na značaj koji za pojavu i razvoj turizma na seljačkim domaćinstvima ima masovni kupališni turizam u priobalju. Također, potvrđena je važna uloga dobne i obrazovne strukture stanovništva.

Ključne riječi: turizam na seljačkim domaćinstvima, ruralni turizam, seoski turizam, tipologija, ruralna područja, faktorska analiza, klaster analiza, tourism.

\section{Introduction}

Tourism and recreation have for decades been one of the responses to various challenges and threats to rural areas across Europe and elsewhere (Adamowicz, 2010; Baležentis et al. 2012,

\footnotetext{
${ }^{1}$ Dr.sc. Aleksandar Lukić, Assistant Professor, University of Zagreb, Faculty of Science, Department of Geography, Marulićev trg 19, 10000 Zagreb, Croatia. E-mail: alukic@geog.pmf.hr
} 
Butler et al., 1998; Cawley and Gillmor, 2008; Hall et al., 2003; Ilbery, 1998; Látková and Vogt, 2011; Sharpley, 2002; Wilson et al., 2001; Woods, 2005). Diverse responses to those challenges could be understood as consequences of how geographically different areas outside cities and towns have faced varied agents of spatial transformations, such as changes in agricultural production or increased demand for countryside amenities (Woods, 2005). As an outcome, one can have witnessed the (re)emergence of heterogeneous and diversified nonurban areas with different demographic, social, cultural, economic, functional, physiognomic and environmental realities. Furthermore, the evolution of social thought and alterations in the materialistic dimensions of rurality has triggered changes in a perspective adopted by different stakeholders when seeing and utilizing rural space, which has accelerated the whole process. Eventually, the identity and discourses in which the rural is perceived, experienced, lived, planned and developed are constantly reconfiguring (Cloke, 2006; Halfacree, 2006). Building on this conceptualization the papers argues that plurality of rurality is becoming increasingly important factor in researching farm tourism development.

Although there are many success stories about diversifying farms into leisure activities as a tool for adapting to the above mentioned new rural realities, farm tourism development has not always followed despite high expectations of it (Briedenhann and Wickens, 2004; Sharpley, 2002). Numerous researches have tried to identify the most important elements constraining or supporting successful development of various forms of farm and rural tourism (Briedenhann and Wickens, 2004; Cawley and Gillmor, 2008; McGeheea et al., 2007; Santana-Jiménez et al., 2011; Sharpley and Vass, 2006; Wilson et al., 2001). However, the gap has been identified in recognizing the linkages between rural diversity (i.e. geographical context), on the one side, with the development of leisure activities, on the other. This is not to say that the geographical context, understood as spatial expression of mutual dependencies between natural, demographical, historical, social, economic, cultural and other elements of place has not been recognized as an important factor (Sznajder et al., 2009). Nevertheless, we suggest that growing number of research on rural diversity using typological approach could be used to further deepen the existing knowledge of complex linkages between factors contributing to successful development of farm diversification into tourism.

The research is positioned within this framework. Its' aims are twofold. Firstly, it aims to explore the significance of rural diversity of Croatia for farm diversification into leisure-orientated activities. The main method is comparison of spatial distribution of households with agricultural production related with tourism, accommodation and other leisure activities (HAPT), on the one hand, and seven different types of rural areas that have been identified using multivariate (factor and cluster) analysis in authors' previous research, on the other. The second aim is to try to recognize, using statistical methods, indicators of rural diversity that influence farm diversification into leisure-orientated activities in Croatia.

\section{Factors contributing to success in farm and rural tourism development - theoretical background}

Success in farm tourism inevitably leads towards discussing at least two important overlapping concepts, namely 1 . The tourism destination and 2. Diversity of rural areas as a setting for tourism development.

\section{Tourism destination: development and competitiveness}

Development and competitiveness of tourism destinations is rich and constantly growing area of research. However, in line with the aims of the paper, the following concise outline is not an attempt to provide comprehensive overview of different theoretical or methodological research models concerning tourism destinations. Some recent papers serve that purpose very well (e.g. Haugland et al., 2011). This paper will strictly aim to reveal critical factors of (rural) tourism destination success according to various selected approaches. Some of the most important approaches recognized are those reflecting on tourist supply and demand, push and pull factors, tourism destination competitiveness (TDC), and various integrated and/or multilevel perspectives on tourism destination development (e.g. IRT). The paper by Lim (1997) offers 
a useful departure point, both conceptually and temporally. The author reviewed 100 empirical studies of international tourism demand models, published mostly in the 1980s (although some date from 1960s, providing a useful long-term overview). According to the paper, the most used factors explaining tourist demand in that period were income, relative prices, tourism prices, and transportation costs. Furthermore, the paper lists exchange rates, trends, dynamics, competing destinations/goods, seasonal factors, marketing expenditures, migration, business travel/trade, economic activity indicators, qualitative and other factors. Qualitative factors, which reveal greater importance of certain aspects of destination attractiveness and uniqueness (e.g. climate, culture, history and natural environment), although present, are not among the most important ones. We would argue that this hierarchy is in line with the concept of mass tourism development dominant in that period.

Going further towards tourist motivation is the second well-known approach: the push-pull framework that provides a useful method for examining the driving forces underlying tourist behavior (Kim et al., 2003). Push factors are explained as the specific forces that influence a person's decision to take a vacation. On the other hand, pull factors refer to the forces that influence the person's selection of specific destination. Although application of this framework has not been very common in recent discussions on farm diversification into tourism, other examples in rural settings offer some insights. For example, the paper by Kim et al. (2003) provides a comprehensive overview of the approach in the context of protected areas and explores the influence of push and pull factors at Korean national parks. The common push factors found in numerous analyzed studies were: escape from everyday environment, novelty, social interaction, and prestige; while those focused specifically on national parks were challenge or adventure, enjoyment, social interaction (building friendship or family togetherness), novelty and religious heritage (especially for Korean National Park visitors). Moving to the pull side of the framework, the analysis of various studies discovered four general dimensions: entertainment, infrastructure, physical environment, and high profile entertainment opportunities. However, the authors warn that pull factors of national parks are likely to be different between countries or their locations and, we would add, should not be generalized uncritically.

In the 1990s, above-mentioned approaches towards tourism destination demand and development have been enriched with the concept of competitiveness. Ritchie and Crouch, the authors of much used model of tourism destination competitiveness (TDC) from the beginning of the 1990s, would even argue that although "...competition occurs between airlines, tour operators, hotels, and other tourism services, this inter-enterprise competition is dependent upon and derived from the choices tourists make between alternative destinations" (Ritchie and Crouch, 2000:1). It is no surprise then that competitiveness is an area of growing interest among tourism researchers, extending and integrating previous studies that focused on supply and demand, push and pull factors, destination image or attractiveness. The updated TDC model identified the following success factors of destination competitiveness and sustainability (summarized by the author):

- Core resources \& attractors (physiography and climate, culture and history, market ties, mix of activities, special events, entertainment, superstructure);

- Destination management (resource stewardship, marketing, finance \& venture capital, organization, human resource development, information/research, quality of service, visitor management);

- Destination policy, planning \& development (system definition, philosophy, vision, audit, positioning, development, competitive/collaborative analysis, monitoring and evaluation);

- Qualifying and amplifying determinants (location, interdependencies, safety/security, awareness/image/brand, cost/value);

- Finally, supporting factors and resources have also been recognized (infrastructure, accessibility, facilitating resources, hospitality, enterprise) (Ritchie and Crouch, 2000). 
Although very comprehensive, several researchers have further built upon this model in various ways. Enright and Newton (2004) for example added generic factors of competitiveness that are applicable to any industry, to the mainstream factors of destination attractiveness. Mihalic (2000) focused more clearly on environmental aspects of competitiveness from a managerial perspective. Her paper concluded that the destination competitiveness could be enhanced through certain environmental marketing activities. The strongest impact was documented in using internationally recognised accreditation schemes (e.g. eco-labels, green brands and trade marks) by independent third organisations or bodies. However, Mihalič (2000) warns that too many environmental signs cause confusion for potential customers and eventually lower the value of every single green brand. To conclude, the question one might ask is whether this competitiveness model is of any great importance for farm tourism? We would argue that although often considered a small and niche market, farm tourism is today, without doubt, part of the global leisure industry with growing importance (Butler et al., 1998). In that sense, the success of farm tourism, on its own or as an integrated part of a complex destination is influenced by its relative competitiveness in world markets.

In the 2000s, a new buzzword seemed to appear in researching tourism development: integrated approach. Growing importance of different stakeholders and structures influencing tourism in rural areas required new concepts of understanding. Furthermore, although integrated approach was a well-known and often used concept in rural development since the second half of the 1980s (which also helped pushing it into a tourism agenda), the fragmentation of research on destination development finally brought it to attention (Haugland et al., 2011). Their paper argues that although existing research had paid attention to a large number of issues concerning destination development, it still left a gap in recognizing strategies "spanning individual actor boundaries" and requiring attention to "issues at the level of the individual actor, the level of the destination (inter-firm or inter-actor), and the level of a larger geographic or regional area (inter-destination)" (Haugland et al., 2011: 269). Identified "major parts" of their integrated, multilevel framework (which could be possibly understood as the factors of success) are: destination capabilities (destination image and branding, utilization of distributed resources and competencies), coordination at the destination level (degree of integration in the local network structure), and inter-destination bridge ties (imitation, innovation). At the moment, the author is not familiar with any concrete application of this model that promises recognizing linkages often left out of research.

In the field of rural tourism studies, the idea of integration has been applied within the concept of "integrated rural tourism" (IRT) conceived as "a method of encapsulating its multidimensional nature and the multiplicity of stakeholders" (Cawley and Gillmor, 2008:317). It is possible to recognize following factors of success in the IRT model: an ethos of promoting multidimensional sustainability, the empowerment of local people, endogenous ownership and resource use, complementarity to other economic sectors and activities, an appropriate scale of development, networking among stakeholders, and embeddedness in local systems (Cawley and Gillmor, 2008:319). The model of IRT was applied, for example, to analyze the value added or taken away by changes in tourism over the years 1992 to 2002 in western Ireland, an area with a long tradition of tourism activities. The evaluation identified dimensions concerning agreement and disagreement among the stakeholders on the factors supporting and constraining sustainability, reflecting growing importance of participatory approaches needed for successful rural tourism development.

The IRT concept helps us now to focus more on tourism (destination) development in rural context. We would argue that by recognizing factors such as embeddedness in local systems and endogenous ownership and resource use, not very common within general approaches to coastal or other mass tourism destinations, the specificities of rural context have been brought to very much needed attention. One of them is, for example, discussion concerning the best possible approach for rural tourism development. Wilson et al. (2001) recognized two opposing views that dominate current debate. The first could be labeled as entrepreneurial, marketoriented approach that draws heavily on the economic literature. It argues that helping and creating individual businesses, and then letting them compete in the market place, best develops tourism and its associated entrepreneurship opportunities. The opposing, community 
approach, argues that "tourism is a community product and that, along with entrepreneurial skills and the presence of tourist businesses, it is also necessary to have the community and local capabilities (e.g. local leadership and formal and informal networks) directly involved" (Wilson et al., 2001:133). Trying to overcome this dualism, their study (focus group methodology) tried to identify those factors that help rural communities successfully develop tourism by also including entrepreneurs. Eventually, numerous important factors have been detected: (1) a complete tourism package, (2) good community leadership, (3) support and participation of local government, (4) sufficient funds for tourism development, (5) strategic planning, (6) coordination and cooperation between businesspersons and local leadership, (7) coordination and cooperation between rural tourism entrepreneurs, (8) information and technical assistance for tourism development and promotion, (9) good convention and visitors bureaus, and (10) widespread community support for tourism (Wilson et al., 2001:134).

Although the list of factors contributing to success in rural tourism development may seem exhausted by now, some studies that focused on certain specific aspects, revealed more interesting elements. Gender was, for example, also identified as an important factor. Results of the study by McGehee et al. (2007) indicate that women were found to have higher motivation for agri-tourism entrepreneurship, even if not consistently significant. Household characteristics could also play an important role in decision to start a tourism-related activity on the farm. Liu et al. (2012) support the hypothesis that the local households' livelihood assets (i.e., financial, human, natural, physical, and social capitals) have an effect on the likelihood to participate directly in tourism. Their research concluded that, "in general, households with greater financial (e.g., income), physical (e.g., access to key tourism sites), human (e.g., education), and social (e.g., kinship with local government officials) capitals and less natural capital (e.g., cropland) were more likely to participate in tourism activities" (Liu et al., 2012:1). In the line with placeoriented nature of rural tourism (Wilson et al., 2001), the importance of land use diversity and remoteness has also been correlated with tourism setting. Santana-Jiménez et al. (2011) has found positive influence of those factors for the rental price of the house, an important factor in tourism development.

This short overview of factors contributing to and deterring development of tourism and other leisure-oriented activities in rural areas clearly reveals huge complexities. It is becoming evident that any single approach is insufficient to holistically examine numerous factors and their mutual dependencies. However, although different physical, natural, human, social, economic, and cultural assets are often analyzed as important parts of different theoretical models and empirical research, we would argue that spatial diversity, which is the result of their linkages, is often foreseen. We continue therefore this paper with concise introduction to diversity of rural areas and typologies as an instrument for its identification. After that, the paper continues with the role of diversity of rural areas in Croatia for farm tourism development.

\section{Diversity of rural areas as a setting for farm tourism development}

As discussed in the previous chapters, different theoretical and methodological approaches are possible in dealing with the importance of factors and geographical context for farm and rural tourism development. Diversity of rural areas as a setting for tourism development is in one way or another used in numerous approaches. However, the gap was identified in researching the importance of different types of rural areas as a setting for development and success of farm tourism.

As already noted, contemporary differentiated countryside could be understood as the result of diverse responses to numerous challenges faced by rural areas (Woods, 2005). As an outcome, one can have witnessed the (re)emergence of heterogeneous and non-urban areas with different demographic, social, cultural, economic, functional, physiognomic and environmental realities. The differentiated view has been prominent not only in academic reading of the countryside, but also within the political context. The most important process that changed the way rural areas are being dealt with in the political context was the decline in the importance of agriculture in the economy. Planning and policy-making in rural areas turned away from a sectoral (agricultural) basis and turned towards a place-based approach supporting the economic performance, social inclusion and environmental assets of rural localities (OECD, 
2006; Shucksmith, 2010). Eventually, this led to multidimensional approach to researching plurality of rurality, revealing the connections between numerous characteristics of rural areas and seeing "the big picture". This approach was markedly different from the earlier attempts, which have usually focused on quantifying degree or index of rurality (e.g. Harrington and O'Donoghue, 1998). However, in both approaches typologies have been recognized as a useful tool in empirically researching plurality. ${ }^{2}$

Typology of rural areas in the EC document The future of rural society (1988), which recognized three standard problems of European rural areas (the pressure of modern life, rural decline and marginalization), and classified areas accordingly (integrated, intermediate and remote rural areas), is, to authors' knowledge, the first attempt to recognize plurality of rurality within the political context. Later, in the 1990s and 2000s, typologies based on advanced statistical techniques and GIS have been produced both in ESDP and ESPON (Bengs and SchmidtThomé, 2006). Finally, descriptive rural area types recognized in the background document for the The Territorial Agenda of the European Union 2020 (TA2020), arguably the most important political framework concerning spatial planning and territorial development, were the last in the row of typological analysis of European territory. The TA2020 typology recognized four different territorial types in EU countries: accessible rural territories in the metropolitan centres' surroundings, remote rural areas, internal rural peripheries and traditional agricultural areas. ${ }^{3}$

Numerous other academic and political attempts to empirically research and understand plurality of European rural areas were also present. Ballas et al. (2003) and Gülümser et al. (2007) provided recent overview of typological approaches to diversity of rural areas. However, in order to research empirical treatment of plurality in more details, author analyzed numerous typologies of rural areas (Lukić, 2012): Bosna and Herzegovina (Meredith, 2007), Canada (Reimer, 2002), Finland (Malinen n.d.), Greece (Benaki et al. n.d.; Benaki et al., 2005) Ireland (Centre for Local and Regional Studies - NUI Maynooth and Brady Shipman Martin, 2000), Crete (lliopoulou et al., 2006), USA (Berry et al., 2000), Serbia (Meredith, 2006), United Kingdom (Harrington and O'Donoghue, 1998; Marsden, 1998) EU (Politecnico di Milano, 1999; Ballas et al., 2003)., SAD (2004), Slovenia (Kladnik and Ravbar, 2003; Perpar and Kovačič, 2002).

Comparative analysis of above-mentioned typologies was conducted in order to identify: 1. Variables and data requirements, 2. Spatial level of analysis, 3. Methodological approach and 4. Basic results, i.e. number of types and their names. Following conclusions were made:

1. Approaches to creating typologies can be divided into aggregative and disaggregative. In aggregative approaches individual spatial units are gathered into larger clusters based on their mutual similarities. In disaggregative approaches all spatial units are observed as a single group divided into a number of subgroups, based on predefined criteria.

2. Typology is a highly selective instrument in research and it depends on the selection of variables and spatial level.

3. Variables that are used can be divided into several basic groups: general geographic indicators (locational, topographic), demographic structure and dynamics, socio-economic structure of population, the importance of agriculture and accessibility.

4. In creating synthetic, multidimensional typologies through aggregative approach, the application of interdependent techniques of multivariate analysis (factor and cluster analysis) is dominant.

5. It is important to observe rural and urban areas in their interdependency.

\footnotetext{
${ }^{2}$ Although typologies, especially those based on advanced multivariate techniques have been present in geography and other spatial studies since at least mid- $20^{\text {th }}$ century (Robinson, 2008), they have become more and more prominent in rural studies in the 1980s.

3 The Territorial State and Perspectives of the European Union, 2011 update, Background document for the Territorial Agenda of the European Union 2020, (2011:55-57).
} 
The comparative analysis of selected typologies was also very useful in recognizing data requirements and data collection approaches. Typology of rural and urbanized settlements in Croatia, explained in the following part of the paper, has been constructed in the line with the abovementioned insights.

To conclude, typologies have been used as an instrument for identification of territorial differences, as well as for systematization, comparison and analysis of the collected information. Today, typologies of rural and urbanized areas are common in spatial and regional strategies of European countries. They might be especially useful in constructing the "big picture" and thus overcoming the discordance among the policies influencing development in rural areas at the national level (rural policy, regional policy, spatial/town and country planning systems etc.).

However, although empirical treatment of plurality of rurality based on typological approach is the most used approach, it is certainly not the only possible method. The evolution of social thought and alterations in the materialistic dimensions of rurality has triggered changes in a perspective adopted by different stakeholders when seeing and utilizing rural space. This is a very dynamic process that is very hard to grasp by any statistically based approach. The identity and discourses in which the rural is perceived, experienced, lived, planned and developed are constantly reconfiguring (Cloke, 2006; Halfacree, 2006) and it is worth keeping that in mind when typologies are used.

\section{Typology of rural and urbanized settlements in Croatia}

Rural and urbanized settlements in Croatia constitute around $90 \%$ of the total area and are home to around $46 \%$ of the population disproportionately distributed in the country ${ }^{4}$. This is the reflection of urbanization and modernization processes which have, in various and constantly transformative forms, unevenly swept the countryside: between 1961 and 2001, the population of more than $80 \%$ of all rural settlements was reduced, with half of them shrinking by at least $50 \%$, mainly as a result of long-term depopulation, "de-agrarization" and pauperisation triggered already in the $19^{\text {th }}$ century by the economic and political crises, followed by overseas emigration (Lukić, 2012). The polarization of regional development intensified in the socialist period with strong industrialization and littoralization, transforming some areas into suburban zones, others into over-built tourist settlements and some into peripheral and marginal areas. The Homeland War (1991-1995) and the transition into a market economy were among the last very influential elements of spatial and regional transformation of the country.

\footnotetext{
${ }^{4}$ The latest official statistical research on urban and rural population in Croatia states that $46.4 \%$ of total population could be considered rural and non-urban (mixed) (Ostroški, 2011).
} 


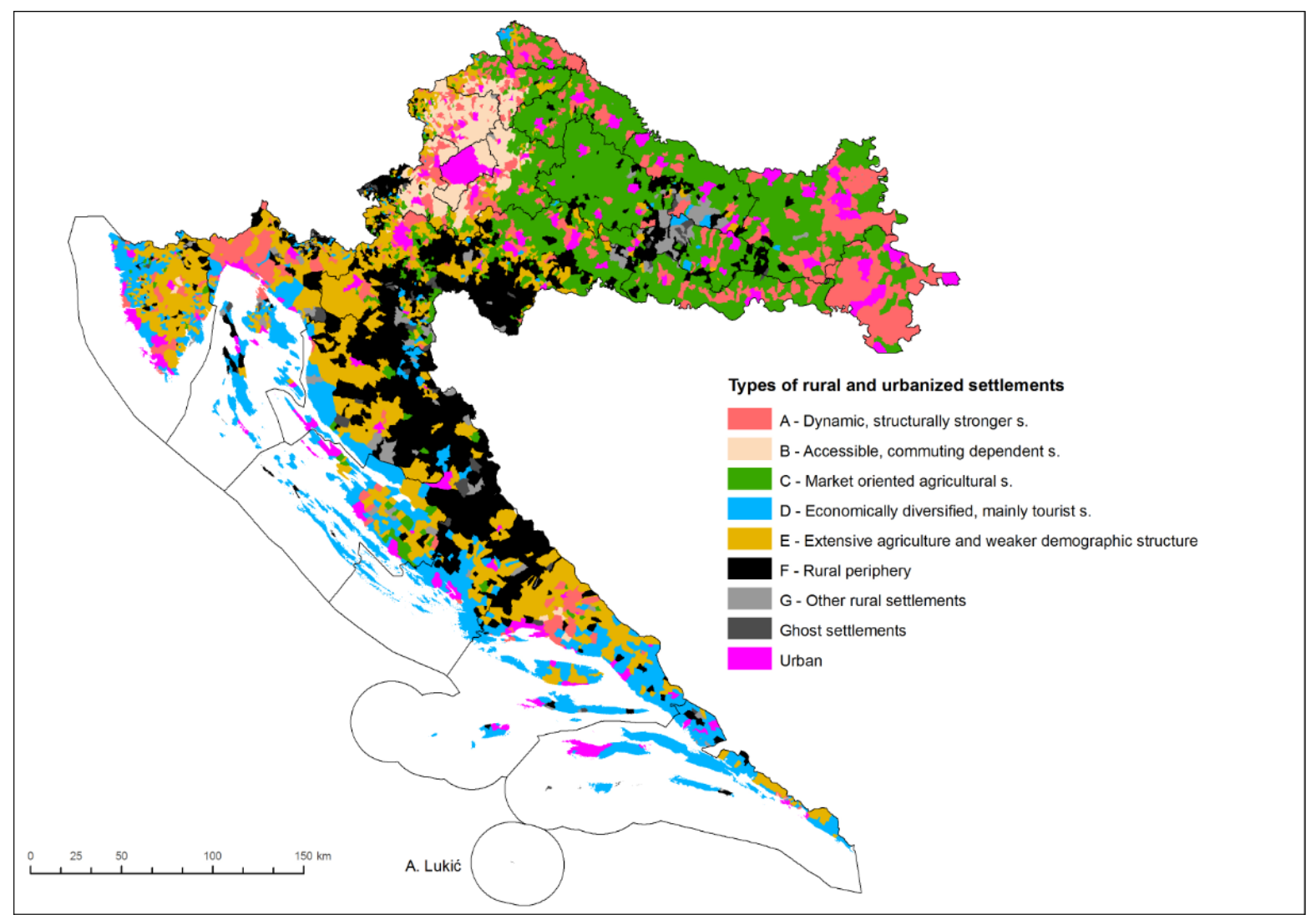

Fig 1. Typology of rural and urbanized settlements in Croatia. Source: Lukić, 2012.

Typology based on multidimensional aggregative approach has been developed in order to spatially recognize the abovementioned differences among non-urban settlements, using 59 variables in 10 categories (Appendix 1) (Lukić, 2012). The categories used in the analysis are: topography; size, distribution, and population structure; demographic dynamics; employment and commuting; socio-economic structure of settlements; importance and structure of agriculture as a source of income; land use; functions and shape of housing; household equipment; settlement centrality and accessibility by road. We argue that these are partially similar to variables that have been considered important for farm tourism development, as revealed in the literature overview. The principal components and factor analysis have resulted in 8 factors, which have been used in a cluster analysis. Finally, 7 types have been recognized (one being residual with $0.2 \%$ of total population) (Fig. 1, Tab. 1 and Tab. 2).

\footnotetext{
${ }^{5}$ Detailed overview of the variables is given in the Appendix 1. Most of them were obtained by special analysis on settlement level (6759) of census data provided by Croatian Bureau of Statistics. The analysis included the following three data sources: the 2001 Census of Population, Households and Dwellings; the 2003 Agricultural Census and Report on Sale Capacities in Retailing in 2004. Vital statistics data for the period 2001-2006 were also used. Data used to determine the level of settlement centrality were obtained from relevant institutions and from their official web pages. The techniques used in the analysis were descriptive statistics (shares, indices), cartographic visualisation and interdependent techniques of multivariate analysis: factor and cluster analyses. The software used in analyzing the data were MS Excel, MS Access, SPSS 12.0 for Windows, ArcGIS 9.2 and Network Analyst extension. The time frame of the research is from 2001 to 2008 during which three key databases were published and data about central functions of settlements was collected, with the exception of the data regarding the settlement size (the population change index was calculated by using the data from the period 1961-2001).
} 


\begin{tabular}{|c|c|}
\hline $\begin{array}{l}\text { Type of rural and } \\
\text { urbanized settlements }\end{array}$ & Selected characteristics \\
\hline $\begin{array}{l}\text { A } \\
\text { Dynamic, structurally } \\
\text { stronger rural and } \\
\text { urbanized settlements } \\
\text { (688 settlements, } \\
747,054 \text { people) }\end{array}$ & $\begin{array}{l}\text { Predominantly in close proximity of important urban centres in the country, alongside } \\
\text { the main axes of urbanization in Central and Eastern Croatia and large settlements } \\
\text { in Eastern Croatia (developed central functions). The average population is } 1085.8 \text {, } \\
\text { with the population density of } 102.5 \text { people//km². The biggest and most densely } \\
\text { populated type. The best age and educational structure of population. Strong } \\
\text { demographic concentration is connected with (sub)urbanization, a key process } \\
\text { contributing to population growth during the last } 30 \text { to } 40 \text { years. The proportion of } \\
\text { employed daily commuters is very high. Although the secondary (industrial) sector } \\
\text { has the highest share compared to the other types, the proportion of used } \\
\text { agricultural land is still relatively high. }\end{array}$ \\
\hline $\begin{array}{l}\text { B } \\
\text { Accessible, commuting } \\
\text { dependent rural and } \\
\text { urbanized settlements } \\
\text { (638 settlements, } \\
200,609 \text { people) }\end{array}$ & $\begin{array}{l}\text { Strong regional component in spatial distribution (Zagreb surroundings and Hrvatsko } \\
\text { Zagorje). Settlement size is smaller (with average population of } 314.4 \text { and } 43.2 \% \text { of } \\
\text { all settlements containing less than } 100 \text { residents), they are more scarcely populated } \\
\text { ( } 85.5 \text { people/sq.km) and with less developed central functions (in comparison with } \\
\text { the type A). Stronger rural characteristics, especially physiognomically (smaller size, } \\
\text { higher proportion of agricultural households and twice the size of agricultural } \\
\text { population). They are very accessible from the network of central settlements. } \\
\text { Zagreb's recreational zone (high share of secondary homes). }\end{array}$ \\
\hline $\begin{array}{l}\text { C } \\
\text { Market oriented } \\
\text { agricultural rural and } \\
\text { urbanized settlements } \\
\text { (1710 settlements, } \\
522,234 \text { people) }\end{array}$ & $\begin{array}{l}\text { Agriculture is a vital source of household income and it is very market orientated. } \\
\text { Almost } 50 \% \text { of agricultural land in Croatia. Average population of a settlement is } \\
305.4 \text {, with average population density of } 38.4 \text { people/km². Location: mostly Eastern } \\
\text { Croatia but are also important in Daruvar, Bjelovar and Križevci area in Central } \\
\text { Croatia as well as some parts of Podravina and Međimurje. Its spatial distribution is } \\
\text { primarily the reflection of favourable natural conditions. Highest proportion of } \\
\text { households that generate income from agricultural sales, total used agricultural land } \\
\text { on a tenure, proportion of used agricultural land and the highest average size of lot } \\
\text { as well as proportion of agricultural households with over } 20 \text { ha of total available } \\
\text { land. These areas were mostly immigration zones in continental Croatia used for } \\
\text { unburdening agriculturally overpopulated areas, at the same time demographically } \\
\text { strengthening them and rejuvenating them. }\end{array}$ \\
\hline $\begin{array}{l}\text { D } \\
\text { Economically } \\
\text { diversified, mainly } \\
\text { tourist rural and } \\
\text { urbanized settlements } \\
\text { (913 settlements, } \\
267,833 \text { people) }\end{array}$ & $\begin{array}{l}\text { Narrow coastline, islands and certain smaller areas of touristically developed or } \\
\text { economically diversified hinterland are predominant. With strong concentration of } \\
\text { tertiary sector, the type forms the core areas of Croatian tourism. The average } \\
\text { population of a settlement is } 293.4 \text {, and the density is } 35.2 \text { people/km². It also } \\
\text { encompasses areas where agricultural households diversify in other economic } \\
\text { activities beside tourism. It has on average the highest proportion of secondary } \\
\text { homes, and by far the highest proportion of agricultural households, which are } \\
\text { employed in tourism, accommodation, and other leisure activities. The natural } \\
\text { population dynamics indicators are on average more favourable compared to } \\
\text { the other types, with the exception of the type A. }\end{array}$ \\
\hline $\begin{array}{l}\text { E } \\
\text { Rural and urbanized } \\
\text { settlements of } \\
\text { extensive agriculture } \\
\text { and weaker } \\
\text { demographic structure }\end{array}$ & $\begin{array}{l}\text { Areas of dilution of life substance, only differing in intensity. There are large areas } \\
\text { with distinct concentration of settlements of these two types. Apart from those areas, } \\
\text { both types can be found as "pockets" of extensification and periphery in all Croatian } \\
\text { regions, mostly in mountainous and cross-border areas and coastland hinterland as } \\
\text { well as in the interior of the islands. } \\
\text { Continuous zones: Type E: Central and Northern Istra, type F: Lika, Kordun, } \\
\text { Banovina and Šibenik Zagora (hinterland). In Gorski kotar and Karlovac Pokuplje } \\
\text { both types are mixed. }\end{array}$ \\
\hline $\begin{array}{l}\text { (1380 settlements, } \\
239,985 \text { people) }\end{array}$ & $\begin{array}{l}\text { "Pockets" type E: some cross-border areas of Hrvatsko Zagorje, Bukovica, parts of } \\
\text { Cetina and Imotski area and Konavle. "Pockets" type F: Žumberak and Slavonian } \\
\text { mountains (Papuk, Psunj, Dilj, Krndija). }\end{array}$ \\
\hline $\begin{array}{l}\text { F } \\
\text { Rural periphery } \\
\text { (991 settlements, } \\
58,317 \text { people) }\end{array}$ & $\begin{array}{l}\text { All demographic indicators are negative, especially in the type F. What is different in } \\
\text { demography of these two types is the age and education structure and indicators of } \\
\text { natural population change. In rural periphery, all of the aforementioned indicators are } \\
\text { on a very low level. Rural periphery is dependent on agriculture and the primary } \\
\text { sector, weak market orientation. Mobility of population: the type } E \text { has a higher } \\
\text { proportion of daily commuters in labour force by which it compensates for its weak } \\
\text { economic basis. }\end{array}$ \\
\hline
\end{tabular}

Tab 1. Selected characteristics of rural and urbanized settlements types in Croatia Source: Lukić, 2012. 


\begin{tabular}{|c|c|c|c|c|c|c|c|c|c|}
\hline & \begin{tabular}{|l|} 
Settle- \\
ments \\
(Share \\
in total) \\
\end{tabular} & $\begin{array}{l}\text { Area } \\
\left(\mathrm{km}^{2}\right) \\
(\text { Share } \\
\text { in total) } \\
\end{array}$ & $\begin{array}{l}\begin{array}{l}\text { Population } \\
\text { (Share } \\
\text { in total) }\end{array} \\
\end{array}$ & $\begin{array}{l}\text { Av. sett. } \\
\text { size }\end{array}$ & $\begin{array}{l}\text { Pop. } \\
\text { density }\end{array}$ & $\begin{array}{l}\text { Agri. } \\
\text { household } \\
\text { (Share } \\
\text { in total) } \\
\end{array}$ & $\begin{array}{l}\text { Accessibility } \\
\text { to central } \\
\text { settl. } \\
\text { (Score) } \\
\end{array}$ & $\begin{array}{l}\text { Coastal } \\
\text { settlements }\end{array}$ & $\begin{array}{l}\text { Av. } \\
\text { altitude } \\
\text { of sett. }(\mathrm{m})\end{array}$ \\
\hline $\bar{A}$ & $\begin{array}{l}688 \\
(10,2) \\
\end{array}$ & $\begin{array}{l}7286,3 \\
(12,9)\end{array}$ & \begin{tabular}{|l|}
747.054 \\
$(16,8)$
\end{tabular} & 1085,8 & 102,5 & 47,5 & 53,6 & 31 & 175,3 \\
\hline$B$ & \begin{tabular}{|l|}
638 \\
$(9,4)$ \\
\end{tabular} & $\begin{array}{l}2347,4 \\
(4,1)\end{array}$ & \begin{tabular}{|l|}
200.609 \\
$(4,5)$
\end{tabular} & 314,4 & 85,5 & 65,7 & 97,9 & 0 & 204,4 \\
\hline$C$ & $\begin{array}{l}1710 \\
(25,3)\end{array}$ & $\begin{array}{l}13.608,2 \\
(24,0)\end{array}$ & \begin{tabular}{|l|}
522.234 \\
$(11,8)$
\end{tabular} & 305.4 & 38,4 & 73,4 & 30,9 & 0 & 152,2 \\
\hline $\bar{D}$ & \begin{tabular}{|l|}
913 \\
$(13,5)$ \\
\end{tabular} & $\begin{array}{l}7606,0 \\
(13,4)\end{array}$ & \begin{tabular}{|l|}
267.833 \\
$(6,0)$
\end{tabular} & 293.4 & 35,2 & 43,0 & 20,0 & 309 & 155,0 \\
\hline$E$ & $\begin{array}{l}1380 \\
(20,4)\end{array}$ & $\begin{array}{l}10.132,8 \\
(17,9)\end{array}$ & \begin{tabular}{|l|}
239.985 \\
$(5,4)$
\end{tabular} & 173,9 & 23,7 & 63,6 & 24 & 9 & 302,6 \\
\hline$F$ & $\begin{array}{l}991 \\
(14,7) \\
\end{array}$ & $\begin{array}{l}10.203,24 \\
(18,0)\end{array}$ & $\begin{array}{l}58.317 \\
(1,3) \\
\end{array}$ & 58.8 & 5,7 & 73,9 & 14,2 & 7 & 328,6 \\
\hline $\bar{G}$ & $\begin{array}{l}195 \\
(2,9) \\
\end{array}$ & $\begin{array}{l}1415,183 \\
(2,5)\end{array}$ & $\begin{array}{l}7682 \\
(0,2) \\
\end{array}$ & 39.4 & 5,4 & 10,1 & 15,8 & 20 & 273,7 \\
\hline$H$ & $\begin{array}{l}139 \\
(2,1) \\
\end{array}$ & $\begin{array}{l}3411,7 \\
(6,0)\end{array}$ & \begin{tabular}{|l|}
2.393 .746 \\
$(53,9)$
\end{tabular} & $17.221,2$ & 701,6 & 8,7 & 42,6 & 49 & 117,1 \\
\hline \multicolumn{5}{|c|}{$\begin{array}{l}\text { A - Dynamic, structurally stronger rural and } \\
\text { urbanized settlements } \\
B \text { - Accessible, commuting dependent rural } \\
\text { and urbanized settlements } \\
C \text { - Market oriented agricultural rural and } \\
\text { urbanized settlements } \\
D \text { - Economically diversified, mainly tourist } \\
\text { rural and urbanized settlements }\end{array}$} & \multicolumn{5}{|c|}{$\begin{array}{l}\text { E-Rural and urbanized settlements of extensive agriculture } \\
\text { and weaker demographic structure } \\
F-\text { Rural periphery } \\
\text { G-Other rural areas (mostly small settlements with poor } \\
\text { housing conditions) } \\
H \text { - Urban areas }\end{array}$} \\
\hline
\end{tabular}

Tab 2. Selected statistical differences between rural and urbanized settlements types in Croatia.

\section{Development of Farm Tourism in Croatia}

Croatia is a country with a long tradition in tourism. Exceptional natural and geographic conditions, abundance of historical and cultural heritage, favorable traffic position and integration into Mediterranean and Central European culture have given impetus to tourism development in mid-19th century. A century later, Croatian tourism was based on mass ("sunbathing") tourism, and the Adriatic Coast has become a dominant tourist zone. Islands and rural areas on the coast have been urbanized on various scales and affected by second-homes construction. New accommodation facilities such as hotels and company rest houses have been built and many people left agriculture to work in mass tourism in cities and newly built resorts. Villages away from the coast and many islands have been affected by strong depopulation. Although there have been some examples of successful integration of maritime and rural tourism, farm tourism - as a tourism product - did not really exist. However, especially on islands and in Dubrovnik, many hinterland farms have been receiving guests for decades, whether in cooperation with tourist agencies or on their own. Tourism in continental rural areas, especially farm tourism, has also been marginalised. National parks, like Plitvice Lakes for example, have been the only places in rural areas with a rather developed tourist infrastructure and a greater number of visits. Consequently, farm tourism is one of the weakest forms of tourist sector in Croatia.

Before the transition into market economy, there were officially only a few tourist farms in Croatia. New political and economical situation affected Croatia and other ex-socialist countries in the beginning of the 1990s. Denationalization of agricultural land and properties, recognition of private ownership without limitations on farm size and break-up and transformation of stateowned agro-industrial complexes (kombinati) put farmers in Croatia in a different position. They were affected by political and economic crisis caused by aggression against Croatia and transition into liberal market economy, but they had the opportunity to become entrepreneurs. At the same time, there appeared new shifts in international tourist demand and trends towards an individual, sustainable and heritage-oriented tourism. Croatian Farmers Union (Savez 
seljaka Hrvatske) gave one of the first impetuses for farm tourism development. Some initial research has been conducted by Institute of Tourism (Zagreb). Ministry of Tourism as well as Croatian Chamber of Economy supported the development of rural tourism. For-profit consultant companies (Croatian Farmer) and many non-governmental organizations contributed to the development of different forms of tourism in rural areas (Lukić, 2001). By the mid 1990s Croatia had legislation which recognized farm tourism (Franić and Grgić, 2002). First farms with accommodation and other leisure-oriented activities appeared, amounting to 352 in 2007, according to the last research carried out by Croatian Chamber of Economy showing that Istria and Dubrovnik-Neretva County, the northernmost and the southernmost littoral counties, respectively, accounted for $38 \%$ of the total number of officially recognized tourist farms. According to that research, total number of tourist beds on officially recognized tourist farms was 886 (Demonja and Ružić, 2011).

However, the number of farms diversified in tourism, accommodation or other leisure activities is certainly bigger and there are also various other small enterprises in rural areas offering similar products. For example, in Agricultural Census from 2003, 4506 Households with Agricultural Production - Tourism, accommodation and other leisure activities (HAPT) were recognized. The difference between 352 and 4506 is huge and reflect the complexity of defining and researching farm diversification into tourism as well as local specificities. Personal knowledge and fieldwork experiences support the fact that many of those 4506 HAPT are not "working farms", or they do not produce for the market. However, they have some form of gainful leisureoriented activities that yield income. ${ }^{6}$ In many cases, they just rent out a room (so-called Zimmer frei economy).

In conclusion, legal framework is still considered not adequate enough to support and recognize all different forms of leisure-oriented diversification of farms. Their promotion also seems inadequate. Although some counties have their own catalogues directed to rural and farm tourism, such catalogue does not exist for the whole Croatia. Furthermore, even though legislation exists, Croatia has still not categorized its tourist farms (only rooms on the farms are categorized).

\section{Making the Connection - Rural Diversity and Farm Tourism Development}

The first aim of this paper is to recognize and explain some of many possible relations between farm tourism in Croatia, on the one side, and diversity, plurality and geographic context of the countryside, on the other. This is done by analyzing relationships between spatial distribution of the above-mentioned Households with agricultural production - tourism, accommodation and other leisure activities (HAPT) and different types of rural and urbanized settlements in Croatia (Fig.1., Tab.1.).

4506 households with agricultural production - tourism, accommodation and other leisure activities (HAPT) are located in 538 settlements. They are present in all but one type of rural and urbanized settlements (Tab. 3, Fig. 2). Most of HAPT are located in the littoral counties (3492 or $77.6 \%$ ), reflecting the importance of mass-tourism for the development of farm tourism in Croatia. This is also confirmed by the fact that the greatest number of settlements with HAPT belong to economically diversified, mainly tourist rural and urbanized settlements.

\footnotetext{
${ }^{6}$ According to the Agricultural Census (2003) a household with agricultural production is any family or other community of persons who live together and spend their income together for meeting the basic life needs, or any person living alone (single-person household), which engages in agricultural production, or has an agricultural holding, which has a single management, and uses jointly the means of production (machines, facilities, and land) and the work of the members of the household, regardless of whether its production is for personal needs alone or for sale. An agricultural holding is an independent unit which has a single management, uses the means of production (machines, facilities, land, etc.) and produces agricultural products and/or rear cattle, keeps poultry, bees, and rears other animals. Data on households with agricultural production are collected by using the interview method on census forms filled out by the enumerators.
} 


\begin{tabular}{|l|c|}
\hline Types of rural and urbanized settlements & $\begin{array}{c}\text { Number of settlements } \\
\text { with at least one HAPT* }\end{array}$ \\
\hline A - Dynamic, structurally stronger rural and urbanized settlements & 49 \\
\hline B - Accessible, commuting dependent rural and urbanized settlements & 18 \\
\hline C - Market oriented agricultural rural and urbanized settlements & 21 \\
\hline $\begin{array}{l}\text { D - Economically diversified, mainly tourist rural and urbanized } \\
\text { settlements }\end{array}$ & 326 \\
\hline $\begin{array}{l}\text { E - Rural and urbanized settlements of extensive agriculture and weaker } \\
\text { demographic structure }\end{array}$ & 54 \\
\hline F - Rural periphery & 12 \\
\hline $\begin{array}{l}\text { G - Other rural areas (mostly small settlements with poor housing } \\
\text { conditions) }\end{array}$ & 0 \\
\hline H - Urban areas & 58 \\
\hline Total & $\mathbf{5 3 8}$ \\
\hline
\end{tabular}

Tab 3. Distribution of settlements with households with agricultural production - tourism, accommodation and other leisure activities (HAPT) in different types of rural and urbanized settlements in Croatia. Source: Agricultural census 2003., Croatian Bureau of Statistics (for *Households with agricultural production - tourism, accommodation and other leisure activities); Lukić, 2012.

These are mostly areas with a strong concentration of tertiary sector jobs forming the core of Croatian tourism. Beside their concentration along the coast, settlements of this type are located in greater number in the vicinity of some nature protected areas in the continental part of Croatia, reflecting the importance of natural heritage for their development (Fig. 3). On the other hand, the smallest share of settlements with HAPT is in Rural periphery type $(2.2 \%$ of total settlements with HAPT). Although it encompasses $18 \%$ of the territory of Croatia, it is home to only $1.3 \%$ of the total population. Mountainous areas, coastland hinterland, interior of the islands and some cross-border areas are prevalent in this type. They are predominantly characterized by karst geomorphology, higher altitude and relief energy hindering the possibilities for demographic and socio-economic development.

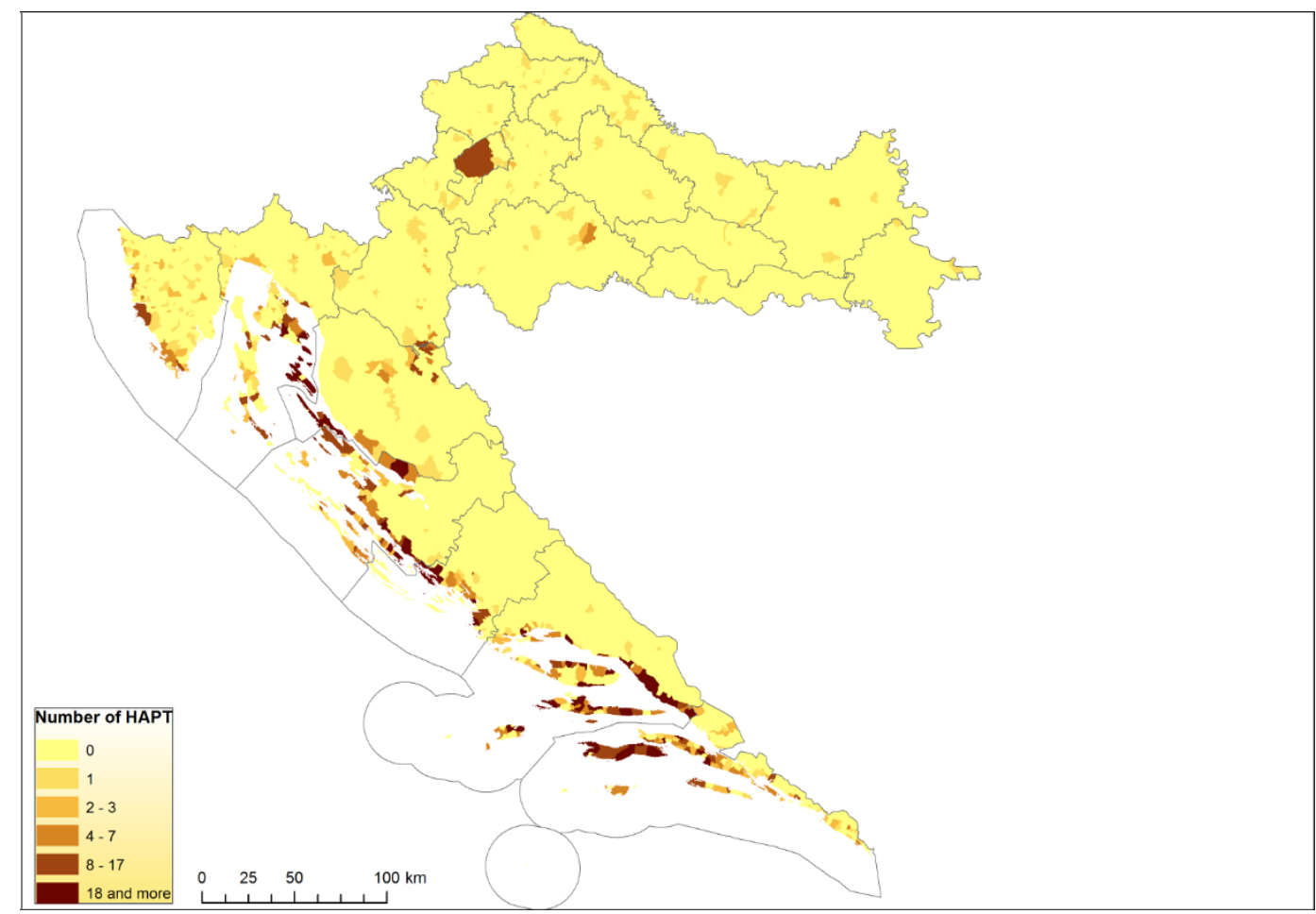

Fig 2. Spatial distribution of households with agricultural production - tourism, accommodation and other leisure activities (HAPT). Source: Agricultural census 2003, Croatian Bureau of Statistics (for *Households with agricultural production - tourism, accommodation and other leisure activities). 
It is also quite interesting to see that the number of settlements with HAPT in Market oriented agricultural rural and urbanized settlements is quite low (3,9\% of total settlements with HAPT). We argue that while this type could offer numerous meaningful connections between tourism and agriculture (e.g. almost $50 \%$ of agricultural land in Croatia), its strong orientation towards commercial and large-scale agriculture (in Croatian terms) is actually not fruitful for making that happen at the moment. Concentration of settlements with HAPT is also visible in the vicinity of urban areas, both in very close proximity (e.g. in settlements that administratively belong to cities and towns) and further away, pointing out the importance of urban market and transport accessibility for the development of HAPT.

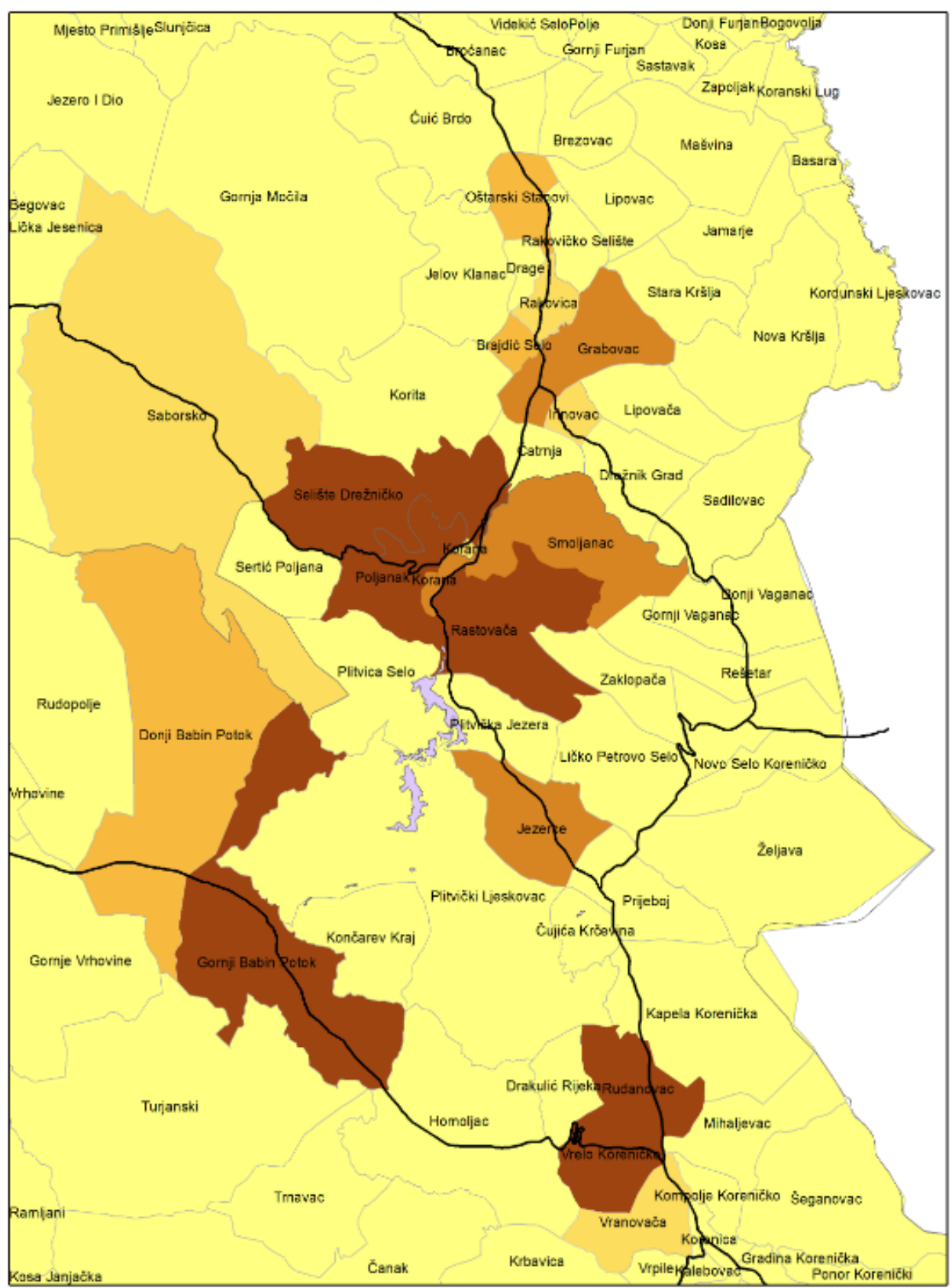

\section{Number of HAPT}
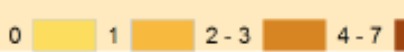

$8-17$

18 and more

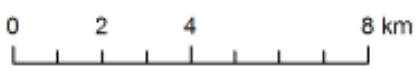

Fig 3. Spatial distribution of households with agricultural production - tourism, accommodation and other leisure activities (HAPT) in the vicinity of Plitvice lakes national park. Source: Agricultural census 2003, Croatian Bureau of Statistics (for *Households with agricultural production - tourism, accommodation and other leisure activities). 
The second aim of the paper was to recognize, using statistical methods, indicators of rural diversity influencing farm diversification into leisure-orientated activities in Croatia. Pearson bivariate correlation analysis was conducted to examine the relationship among the share of HAPT in each settlement with selection of variables used in producing typology of rural and urbanized settlements (Appendix 1). The results indicated that share of HAPT in the settlement has the strongest positive correlation with the share of employees working in hotels and restaurants $(0.32)$ and the share of orchards in the total agricultural land (0.32). These are followed by the share of population with higher education and $\mathrm{PhD}(0.24)$, the share of second homes $(0.20)$, the share of vineyards in the total agricultural land $(0.18)$, the share of households with sewage systems $(0.13)$ and the share of households with water supply systems (0.12). Therefore, those variables could be considered as having an importance in supporting the development of farm tourism. We would argue that they reflect the significance of overall tourist development (exemplified by share of employees working in hotels and restaurants and share of second homes) as a productive milieu for farm diversification into leisure-oriented activities. It also confirms the importance of supportive factor such as household infrastructure. ${ }^{7}$

\begin{tabular}{|c|c|}
\hline Variable & \\
\hline Altitude of the settlement & $-0,14$ \\
\hline Population number 2001 & 0,04 \\
\hline Average household size 2001 & $-0,04$ \\
\hline Population density 2001 & 0,02 \\
\hline Share of young population (0-19) 2001 & 0,01 \\
\hline Share of old population $(60+) 2001$ & $-0,03$ \\
\hline Natural change rate $2001-2006$ & 0,03 \\
\hline Vitality index 2001-2006 & 0,02 \\
\hline Index of biological change 2001-2006 & 0,04 \\
\hline Share of immigrants 2001 & 0,08 \\
\hline Share of population without primary education or with unfinished primary education 2001 & $-0,13$ \\
\hline Share of population with higher education and PhD 2001. & 0,24 \\
\hline Share of commuters 2001 & $-0,05$ \\
\hline Share of active population 2001 & $-0,03$ \\
\hline Share of employed in active population 2001 & 0,00 \\
\hline Share of employed commuters in totally employed in settlement 2001 & 0,03 \\
\hline Share of employed commuters in totally employed 2001 & $-0,04$ \\
\hline Share of employed in primary sector 2001 & $-0,12$ \\
\hline Share of employed in secondary sector 2001 & $-0,04$ \\
\hline Share of employed in hotel and restaurant services 2001 & 0,32 \\
\hline Share of employed in traffic and communications 2001 & 0,02 \\
\hline Share of abandoned homes 2001 & $-0,03$ \\
\hline Share of second homes 2001 & 0,20 \\
\hline Share of households with electricity 2001 & 0,04 \\
\hline Share of households with water supply system 2001 & 0,12 \\
\hline Share of households with sewage system 2001 & 0,13 \\
\hline Share of agricultural households 2001 & $-0,19$ \\
\hline Share of agricultural population 2001 & $-0,07$ \\
\hline Share of active agricultural population in total active population 2001 & $-0,07$ \\
\hline Share of agricultural household members not employed in the household 2003 & 0,09 \\
\hline Share of agricultural household members not engaged in agriculture as their primary occupation 2003 & 0,04 \\
\hline
\end{tabular}

\footnotetext{
${ }^{7}$ Variables concerned with share of orchards and vineyards, although may seem unexpected, are easily explained by the fact that they dominate in littoral part of Croatia, where tourism is highly developed.
} 


\begin{tabular}{|c|c|}
\hline are of agricultural households earning profit from sale of their products 2003 & 0,03 \\
\hline $\begin{array}{l}\text { Share of agricultural households earning profit from sale of crops, fruits, vegetables, grapes and } \\
\text { industrial plants } 2003\end{array}$ & 0,02 \\
\hline Share of agricultural households earning profit from sale of meat diary and poultry products 2003 & $-0,09$ \\
\hline Share of male members of agricultural households 2003 & 0,03 \\
\hline Share of member of households younger than 25 years of age 2003 & $-0,01$ \\
\hline Share of member of households older than 64 years of age 2003 & 0,01 \\
\hline Share of used agricultural land in total available arable land 2003 & $-0,08$ \\
\hline Share of plough-fields in used agricultural land 2003 & $-0,20$ \\
\hline Share of gardens in used agricultural land 2003 & 0,06 \\
\hline Share of meadows in used agricultural land 2003 & $-0,14$ \\
\hline Share of pastures in used agricultural land 2003 & 0,10 \\
\hline Share of orchards in used agricultural land 2003 & 0,32 \\
\hline Share of vineyards in used agricultural land 2003 & 0,18 \\
\hline Share of uncultivated agricultural land in available land 2003 & 0,06 \\
\hline Share of agricultural household with more than 3ha of total usable land 2003 & $-0,06$ \\
\hline Share of used agricultural land in loan 2003 & $-0,05$ \\
\hline Average parcel size of used agricultural land 2003 & $-0,06$ \\
\hline Centrality of the settlement & 0,10 \\
\hline Number of macroregional centres accessible in 30 minutes by car & $-0,04$ \\
\hline Number of regional centres accessible in 30 minutes by car & $-0,07$ \\
\hline Number of subregional centres accessible in 30 minutes by car & $-0,07$ \\
\hline Number of weaker subregional centres accessible in 30 minutes by car & $-0,04$ \\
\hline Number of microregional centres accessible in 30 minutes by car & $-0,09$ \\
\hline Number of local centres accessible in 30 minutes by car & $-0,09$ \\
\hline Number of functionally stronger settlements accessible in 30 minutes by car & $-0,07$ \\
\hline
\end{tabular}

Tab 4. Correlation analysis of Households with agricultural production - tourism, accommodation and other leisure activities (HAPT) and selected variables of rural diversification. Source: Lukić, 2012.

Negative correlation is indicated between the share of HAPT in the settlement and following variables: share of plough-fields in the total agricultural land $(-0.20)$, the share of agricultural households in the settlement $(-0.19)$, the share of meadows in the total agricultural land $(-0.14)$, altitude of the settlement $(-0.14)$, the share of population without primary education or with unfinished primary education $(-0.13)$. Those variables could be considered as currently having negative effect on the farm diversification into tourism and related services.

\section{Conclusion}

Plurality is considered to be one of the most important indicators of rurality in contemporary society, no matter whether we understand rural as a material, imaginative or multifold concept (Halfacree, 2006). In the pluralistic, diversified countryside tourism is certainly one of the activities often promoted and/or used as an important element of countryside sustainable development, or even as a panacea for the marginal rural areas. However, farm, as well as other forms of tourism in rural areas, is strongly dependent on many factors. Literature overview revealed numerous and multiple elements contributing to successful development and competiveness of tourist destination. It also highlighted factors of special importance for the rural context.

The typological approach used in this study aimed to focus more specifically on the geographical context of rural diversity and its role in farm tourism development, which seems to be overlooked in many studies. Typology used as a reference point for the research comprised many of the variables that have been recognized as factor enabling successful tourism development. Besides that, the main advantage was territorial comprehensiveness, 
since it was based on researching the total number of all Croatian rural and urbanized settlements where agricultural households diversified in tourism and related activities are present. This enabled detailed and reliable quantitative analysis.

The most important conclusion is that overall (mass) tourism development, especially but not exclusively along the coast, is the dominant factor contributing to development of tourism on agricultural households. This is clearly confirmed by the experimental results:

1. Most of households with agricultural production - tourism, accommodation and other leisure activities (HAPT) are located in the littoral counties.

2. The greatest number of settlements with HAPT belongs to Economically diversified, mainly tourist rural and urbanized settlements, dominant along the coast and in the proximity to nature protected areas and major urban centres in the continental part of the country. Both are the most important tourist zones outside the Croatian littoral.

3. Pearson bivariate correlation analysis showed that the strongest correlation exists between share of HAPT and share of employees working in hotels and restaurants, clearly indicating the connections between touristic more oriented settlements and agritourism development. This is also confirmed by the fact that share of HAPT is highly correlated with the share of second-homes in the settlement.

On the other hand, it is quite visible that farm tourism is not comprehensively used as a potential tool for regional development in Croatia since the number of settlements with HAPT is very small in the Rural periphery. Peripheral rural areas offer various natural and cultural attractions for tourism development but their demographic structure and social capital are big obstacles. Integral approach to sustainable rural development, where leisure-oriented activities could play an important role, should be envisioned for their future.

The results open up numerous questions. For example, why do we need farm diversification into tourism and leisure-oriented activities? Although this might sound simplistic and selfexplanatory, we would argue that this question is crucial for formulating strategies for the future development. If the main purpose was to enrich already existing mass tourism destinations, as recognized in Croatia, than it would seem that we need almost no strategy at all. However, if we looked at farm diversification as a tool for community-led local development of marginal and peripheral rural areas, than even the best possible tourism strategy would not be of much use. In that case tourism should be the part of integrated strategic development encompassing demographic, social, economic and other aspects of sustainable development. In other words, different rural areas need different developmental strategies. Measures of their success change accordingly. 


\title{
Appendix
}

\author{
Appendix 1. Variables - Typology of rural and urbanized settlements in Croatia \\ Data Sources: \\ 1 - 2001 Census of Population, Households and Dwellings, Croatian Bureau of Statistics \\ 2 - 2003 Agricultural Census, Croatian Bureau of Statistics \\ 3 - Report on Sale Capacities in Retailing in 2004, Croatian Bureau of Statistics \\ 4 - Vital statistics data, Croatian Bureau of Statistics \\ 5 - Relevant Institutions and Companies in Banking, Education, Health Care, Legal System, Retailing, \\ Telecommunications \\ 6 - Digital Relief Model \\ 7 - Digital Atlas of Croatia, GISDATA
}

\begin{tabular}{|l|l|}
\hline CATEGORY & \\
\hline TOPOGRAPHY & \\
\hline SIZE, DISTRIBUTION, AND \\
POPULATION STRUCTURE
\end{tabular}

\section{VARIABLE}

DATA SOURCE

Altitude of the settlemen

Population number 2001

Average household size 2001

Density of population 2001

Share of young population (0-19) 2001

Share of old population $(60+) 2001$

Share of population without primary education or with unfinished primary education 2001

Share of population with higher education and PhD 2001

Share of immigrants 2001

DEMOGRAPHIC DYNAMICS

Population change 1961-2001

Natural change rate 2001-2006

Vital index 2001-2006

Index of biological change 2001-2006

Share of active population 2001

Share of employed in active population 2001

Share of employed commuters in totally employed in settlement

2001

Share of employed commuters in totally employed 2001

Share of commuters 2001

SOCIO-ECONOMIC

STRUCTURE OF

SETTLEMENTS

Share of employed in primary sector 2001

Share of employed in secondary sector 2001

Share of employed in hotel and restaurant services 2001

Share of employed in traffic and communications 2001

Share of agricultural households 2001

IMPORTANCE AND

STRUCTURE OF

AGRICULTURE AS A

SOURCE OF INCOME

Share of agricultural population 2001

Share of active agricultural population in total active population

2001

Share of agricultural households with tourism, accommodation

and other leisure activities 2003

Share of agricultural households with some other non-agricultural gainful activity 2003

Share of agricultural household members not employed in the

household 2003

Share of agricultural household members not engaged in

agriculture as their primary occupation 2003

Share of agricultural households earning profit from sale of their products 2003

Share of agricultural households earning profit from sale of crops,

fruits, vegetables, grapes and industrial plants 2003

Share of agricultural households earning profit from sale of meat

diary and poultry products 2003

Share of male members of agricultural households 2003

Share of member of households younger than 25 years of age 2003

Share of member of households older than 64 years of age 2003

Share of agricultural household with more than 3ha of total usable land 2003

Share of used agricultural land in loan 2003

Average parcel size of used agricultural land 2003 


\begin{tabular}{|l|l|c|}
\hline \multirow{4}{*}{ LAND USE } & Share of used agricultural land in total available arable land 2003 & 2 \\
\cline { 2 - 3 } & Share of plough fields and commercial gardens 2003 & 2 \\
\cline { 2 - 3 } & Share of gardens 2003 & 2 \\
\cline { 2 - 3 } & Share of meadows 2003 & 2 \\
\cline { 2 - 3 } & Share of pastures 2003 & 2 \\
\cline { 2 - 3 } & Share of orchards 2003 & 2 \\
\cline { 2 - 3 } & Share of vineyards 2003 & 2 \\
\cline { 2 - 3 } & Share of uncultivated agricultural land in total available land 2003 & 2 \\
\hline \multirow{5}{*}{ FUNCTIONS AND SHAPE OF } & Share of abandoned homes 2001 & 1 \\
\cline { 2 - 3 } HOUSEHOLD EQUIPMENT & Share of second homes 2001 & 1 \\
\hline SETTLEMENT CENTRALITY & Share of households with electricity 2001 & 1 \\
\cline { 2 - 3 } & Share of households with water supply system 2001 & 3,5 \\
\cline { 2 - 3 } & Share of households with sewage system 2001 & 7 \\
\hline ACCESSIBILITY BY ROAD & Centrality of the settlement & 7 \\
\cline { 2 - 3 } & Number of macroregional centres accessible in 30 minutes by car & 7 \\
\cline { 2 - 3 } & Number of regional centres accessible in 30 minutes by car & 7 \\
\cline { 2 - 3 } & Number of subregional centres accessible in 30 minutes by car & 7 \\
\cline { 2 - 3 } & $\begin{array}{l}\text { Number of weaker subregional centres accessible in 30 minutes } \\
\text { by car }\end{array}$ & 7 \\
\cline { 2 - 3 } & Number of microregional centres accessible in 30 minutes by car & 7 \\
\cline { 2 - 3 } & Number of local centres accessible in 30 minutes by car & 7 \\
\cline { 2 - 3 } & $\begin{array}{l}\text { Number of functionally stronger settlements accessible in 30 } \\
\text { minutes by car }\end{array}$ & 7 \\
\hline
\end{tabular}

Source: Lukić, 2012.

\section{References}

[1] Adamowicz, J. (2010). Towards synergy between tourism and nature conservation. The challenge for the rural regions: The case of Drawskie Lake district, Poland. European Countryside, 2(3), 118-131. Doi: 10.2478/v10091-010-0009-1.

[2] Baležentis, T., Kriščiukaitienè, I., Baležentis, A. \& Garland, R. (2012). Rural tourism development in Lithuania (2003-2010) - A quantitative analysis. Tourism Management Perspectives, 2-3, 1-6. Doi: 10.1016/j.tmp.2012.01.001.

[3] Ballas, D., Kalogeresis, T. \& Labrianidis, L. (2003). A comparative study of typologies for rural areas in Europe [Paper presented at $43^{\text {rd }}$ European Congress of the Regional Science Association, Jyväskylä].

[4] Benaki, V., Alexandrakis, E. \& Apostolopoulos, C. (undated). Entrepreneurial Parameters and Classification - Typology for Rural Areas. Available at: http://www.stats.gov.cn/english/ICAS/papers/P020071114317657343748.pdf [Retrieved 10.3.2008.].

[5] Benaki, V., Rontos, K., Apostolopoulos, C., Kazazis, E. \& Christos, M. (2005). Rural Areas in Greece: Definition, Typology and Data Needs for the Monitoring and Evaluation of Rural Development. Athens: National Statistical Service of Greece.

[6] Bengs, C. \& Schmidt-Thomé, K., ed. (2006). Urban-rural relations in Europe [ESPON 1.1.2, Final report]. Helsinki: Centre for Urban and Regional Studies, University of Technology.

[7] Berry, K. A., Markee, N. L., Fowler, N. \& Giewat G. R., (2000). Interpreting What is Rural and Urban for Western U.S. Counties. Professional Geographer, 52(1), 93-105. Doi: 10.1111/0033-0124.00208.

[8] Boscacci, F., Arcaini, E., Camagni, R., Capello, R., \& Porro, G (1999). A Typology of Rural Areas in Europe: Indicators on Strength and Weakness of Territories and Selection of Areas (NUTS III). Milano: Politecnico di Milano.

[9] Briedenhann, J. \& Wickens, E. (2004). Tourism routes as a tool for the economic development of rural areas-vibrant hope or impossible dream? Tourism Management, 25(1), 71-79. Doi: 10.1016/S0261-5177(03)00063-3. 
[10] Butler, R., Hall, C. M. \& Jenkins, J., eds. (1998). Tourism and Recreation in Rural Areas. Chichester: John Wiley \& Sons.

[11] Cawley, M. \& Gillmor, D. A. (2008). Integrated Rural Tourism: Concepts and Practice. Annals of Tourism Research 35(2), 316-337. DOI:10.1016/j.annals.2007.07.011.

[12] Cloke, P. J. (2006). Conceptualizing rurality (pp. 18-28). In Cloke, P., Marsden, T. \& Mooney, P. H., eds., Handbook of Rural Studies. London: Sage.

[13] Demonja, D. \& Ružić, P. (2011). Ruralni turizam u Hrvatskoj s hrvatskim primjerima dobre prakse i europskim iskustvima. Samobor: Meridijani.

[14] Enright, M. J. \& Newton, J. (2004). Tourism destination competitiveness: a quantitative approach. Tourism Management, 25(6), 777-788. Doi: 10.1016/j.tourman.2004.06.008.

[15] Franić, R. \& Grgić, Z. (2002). Agrotourism on a Family Farm in Croatia - Prospects for Development A Case Study. Agriculturae Conspectus Scientificus, 67(3), 131-141.

[16] Halfacree, K., (2006). Rural space: constructing a three-fold architecture (pp. 44-62). In Cloke, P., Marsden, T. \& Mooney, P. H., eds., Handbook of Rural Studies. London: Sage.

[17] Hall, D., Roberts, L. \& Mitchell, M., eds. (2003). New Directions in Rural Tourism. Aldershot: Ashgate.

[18] Harrington, V. \& O'Donoghue, D. (1998). Rurality in England and Wales 1991: A Replication and Extension of the 1981 Rurality Index. Sociologia Ruralis, 38(2), 178-203. Doi: 10.1111/1467-9523.00071.

[19] Ilbery, B., ed. (1998). The Geography of Rural Change. Harlow: Longman.

[20] lliopoulou, P., Stratakis, P. \& Tsatsaris, A. (2006). Transformation of rural patterns in Greece in a European Regional Development Perspective (The Case of Crete). [Paper read at $46^{\text {th }}$ Congress of the European Regional Science Association "Enlargement, Southern Europe and the Mediterranean «] Volos.

[21] Irish Rural Structure and Gaeltacht Areas (2000). Centre for Local and Regional Studies NUI Maynooth i Brady Shipman Martin.

[22] Kim, S. S., Choong-Ki ,L. \& Klenoskyc, D. B. (2003). The influence of push and pull factors at Korean national parks. Tourism Management, 24(2), 169-180. Doi: 10.1016/S02615177(02)00059-6.

[23] Kladnik, D. \& Ravbar, M., (2003). Členitev slovenskega podeželja. Ljubljana: Geografski inštitut Antona Melika ZRC SAZU.

[24] Látková, P. \& Vogt, C. A. (2011). Residents' Attitudes toward Existing and Future Tourism Development in Rural Communities. Journal of Travel Research, 51(1), 50-67. Doi: $10.1177 / 0047287510394193$.

[25] Lim, C. (1997). Review of international tourism demand models. Annals of Tourism Research, 24(4), 835-849. Doi: 10.1016/S0160-7383(97)00049-2.

[26] Liu, W., Vogt, C. A., Luo, J., He, G., Frank, K. A. et al. (2012). Drivers and Socioeconomic Impacts of Tourism Participation in Protected Areas. PLoS ONE, 7(4), e35420. Doi: 10.1371/journal.pone.0035420.

[27] Lukić, A. (2000). Ruralni turizam - čimbenik integralnog razvitka ruralnih prostora Hrvatske: od mašte do stvarnosti. Geografski horizont, 46(1/2), 7-31.

[28] Lukić, A. (2012). Mozaik izvan grada - tipologija ruralnih i urbaniziranih naselja Hrvatske. Samobor: Meridijani.

[29] Malinen, P. (2000). Rural Area Typology in Finland - marginality within rural areas. [Study Programme on European Spatial Planning (SPESP), final report]. Oulu.

[30] Marsden, T., (1998). New rural territories: Regulating the differentiated rural spaces. Journal of Rural Studies, 14(1), 107-117. Doi: 10.1016/S0743-0167(97)00041-7. 
[31] McGeheea, N. G., Kimb, K. \& Jenningsc, G. R. (2007). Gender and motivation for agritourism entrepreneurship. Tourism Management, 28, 280-289. Doi: 10.1016/j.tourman.2005.12.022.

[32] Meredith, D., (2006). Identification of Rural Regions for Planning Purposes in Serbia. Dublin: The Rural Economy Research Centre.

[33] Meredith, D., (2007). Identification and Classification of Rural Spaces for Planning Purposes in Data Poor Environment: Bosnia and Herzegovina. Dublin: The Rural Economy Research Centre.

[34] OECD (2006). OECD Rural Policy Reviews: The New Rural Paradigm, Policies and Governance. Paris: OECD Publishing.

[35] Ostroški, L. (2011). Model diferencijacije urbanih, ruralnih i prijelaznih naselja u Republici Hrvatskoj. Metodološke upute 67. Zagreb: Državni zavod za statistiku.

[36] Reimer, B., (2002). Exploring Diversity in Rural Canada. Paper prepared for USDA, Economic Research Centre.

[37] Perpar, A. \& Kovačič, M. (2002). Typology and development characteristics of rural areas in Slovenia. Dela, 17, 85-99.

[38] Robinson, G. M. (1998). Methods and Techniques in Human Geography. Chichester: John Wiley \& Sons.

[39] Santana-Jiménez, Y., Suárez-Vega, R. \& Hernández, J. M. (2011). Spatial and environmental characteristics of rural tourism lodging units. Anatolia - An International Journal of Tourism and Hospitality Research, 22(1), 89-101. Doi: $10.1080 / 13032917.2011 .556223$.

[40] Sharpley, R. (2002). Rural tourism and the challenge of tourism diversification: the case of Cyprus. Tourism Management, 23(3), 233-244. Doi: 10.1016/S0261-5177(01)00078-4.

[41] Sharpley, R. \& Vass, A. (2006). Tourism, farming and diversification: An attitudinal study. Tourism Management, 27(5), 1040-1052. Doi: 10.1016/j.tourman.2005.10.025.

[42] Shucksmith, M. (2010). Disintegrated Rural Development? Neo-endogenous Rural Development, Planning and Place-Shaping in Diffused Power Contexts. Sociologia Ruralis 50(1), 1-14. Doi: 10.1111/j.1467-9523.2009.00497.x.

[43] Sznajder, M., Przezbórska, L. \& Scrimgeour L. (2009). Agritourism. Wallingford: CAB International.

[44] Wilson, S., Fesenmaier, D. R., Fesenmaier, J. \& Van Es, J. C. (2001). Factors for Success in Rural Tourism Development. Journal of Travel Research, 40(2), 132-138. Doi: 10.1177/004728750104000203.

[45] Woods, M. (2005). Rural Geography: Processes, Responses and Experiences in Rural Restructuring. London: Sage.

\section{Internet Sources}

[46] Agricultural census 2003. Croatian Bureau of Statistics Available at http://www.dzs.hr)

[47] The future of rural society (1988). Commission communication transmitted to the Council and to the European Parliament. COM (88) 501 final, 28 July 1988. Bulletin of the European Communities, Supplement 4/88, Available at http://aei.pitt.edu/5214/, [Retrieved 21.1.2012.]

[48] Territorial Agenda of the European Union 2020, Towards an Inclusive, Smart and Sustainable Europe of Diverse Region (2011). Available at http://www.eu2011.hu/document/territorial-agenda-european-union-2020-towards-inclusivesmart-and-sustainable-europe-diver [Retrieved 12.2.2012.] 
[49] The Territorial State and Perspectives of the European Union, 2011 update, Background document for the Territorial Agenda of the European Union 2020, (2011). Available at http://www.eu-territorial-agenda.eu/Reference\%20Documents/Forms/Allltems.aspx. [Retrieved 12.2.2012.] 